\title{
Behavioral and physiological effects of a short-term feed restriction in lactating dairy cattle with different body condition scores at calving
}

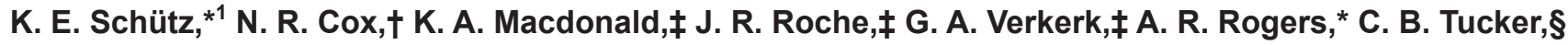 \\ L. R. Matthews,\# S. Meier, $\ddagger$ and J. R. Webster* \\ ${ }^{*}$ AgResearch Ltd., Private Bag 3123, Hamilton 3240, New Zealand \\ †AgResearch Ltd., Private Bag 50034, Mosgiel 9053, New Zealand \\ ‡DairyNZ Ltd., Private Bag 3221, Hamilton 3240, New Zealand \\ §Department of Animal Science, University of California, 1 Shields Ave, Davis 95616 \\ \#Lindsay Matthews and Associates Research International, viale Mario Torinese 38, Scerne di Pineto, Teramo 64025, Italy
}

\begin{abstract}
Body condition score (BCS) around calving, and the typical BCS loss for up to $100 \mathrm{~d}$ after parturition, is associated with both production and reproductive performance of dairy cattle. In addition, there is public concern that thin cows may have impaired welfare, particularly in early lactation where feed demand exceeds pasture growth, and a lag exists between peak milk energy requirements and intake. The aim of this experiment was to determine how BCS at calving influences behavioral and physiological responses to a short-term feed restriction at 47 DIM. Body condition score (on a 10-point scale) at calving was manipulated by modifying the diets in the previous lactation of healthy dairy cattle to generate 3 treatment groups: low BCS (3.4; n $=17)$, medium BCS $(4.6 ; \mathrm{n}=18)$, or high $\mathrm{BCS}(5.4 ; \mathrm{n}$ $=20$ ). Cows were tested in 4 groups for 8 consecutive days; testing consisted of different levels of feed allocation (d 1 and 2: 100\%; d 3 and 4: 75\%; d 5: 50\%; d 6 to 8: $125 \%$ ), where $100 \%$ was $15 \mathrm{~kg}$ of $\mathrm{DM} /$ cow per day. All BCS groups had similar and marked behavioral and physiological responses to feed restriction. For example, they increased vocalization, time spent eating silage and grazing, aggressive behavior, and fat metabolism (as measured by concentrations of $\beta$-hydroxybutyrate and nonesterified fatty acids), and reduced milk production. Body condition affected some of these responses. Fewer cows with low BCS engaged in aggressive interactions in a feed competition test (trough filled with silage that could be consumed in 15 min) on the first day of feed restriction (low: 32\%; medium: 74\%; high: 64\%; standard error of difference $=15.4 \%$ ). High BCS cows had greater concentrations of $\beta$-hydroxybutyrate and nonesterified fatty acids throughout the experimental period, which suggests more fat mobilization; however,
\end{abstract}

Received December 19, 2012.

Accepted March 26, 2013.

${ }^{1}$ Corresponding author: Karin.schutz@agresearch.co.nz plasma leptin and fecal glucocorticosteroid metabolite concentrations were unaffected by BCS. Whereas cows demonstrated marked responses to feed restriction, the results suggest that a BCS of 3.4, 4.6, or 5.4 in healthy cows at calving does not overwhelmingly influence this response at 47 DIM.

Key words: feed restriction, animal welfare, pasture

\section{INTRODUCTION}

Body condition score at calving and the subsequent BCS loss for 50 to $100 \mathrm{~d}$ DIM are associated with production and reproductive performance (reviewed by Roche et al., 2009). When cows are over-conditioned at calving, subsequent health issues and reduced production have been reported. For example, high-producing cows with a high BCS at calving consume less DM in early lactation, produce less milk, and are at increased risk of metabolic disorders, such as ketosis, fatty liver, and milk fever (Heuer et al., 1999; Ingvartsen, 2006; Roche and Berry, 2006; Roche et al., 2009), and are more likely to develop lameness in late lactation (Gearhart et al., 1990). In contrast, cows with a low BCS are at an increased risk of reproductive failure (Heuer et al., 1999; Roche et al., 2007b, 2009) and have low peak milk yield (Frood and Croxton, 1978; Roche et al., 2007a, 2009). In addition, there is public concern that thin cows may have impaired welfare, although the scientific evidence for this is limited.

A cow's BCS may influence how it responds to environmental challenges, such as exposure to inclement weather conditions. Energy reserves are used to mitigate the negative effects of winter weather; therefore, thin cows may be more sensitive to cold weather. When exposed to artificial rain and wind, low BCS cows spent more time eating silage and less time lying down compared with high BCS cows (BCS 4 vs. 9 on a 10-point scale; Tucker et al., 2007). Low BCS cows also had a lower minimum body temperature and NEFA concentrations compared with high BCS cows (Tucker et al., 
2007). Collectively, these results suggest a protective effect of BCS, at least at very high levels of condition, against inclement winter weather.

Feed availability in pasture-based dairy systems varies throughout the year and may sometimes be limited, especially in winter and early spring. This is of particular concern in seasonal calving systems, where feed demand exceeds pasture growth, and a lag between peak milk energy requirements and DMI exists. In general, cattle respond to limited feed availability with a range of behavioral and physiological mechanisms. Behavioral responses to food shortage include increased grazing times (Phillips and Hecheimi, 1989; Gibb et al., 1999; Rook, 2005) and aggression between animals as competition for feed increases (limited feeding space; DeVries et al., 2004). Physiological responses to feed shortage include elevated cortisol (Ward et al., 1992) and NEFA concentrations (Agenäs et al., 2003; Chelikani et al., 2004; Roche, 2007; Laeger et al., 2012), reduced immune function (Moyes et al., 2010), as well as reduced milk production (Agenäs et al., 2003; Roche, 2007). When feed is readily available, low BCS cows consume more feed (Broster and Broster, 1998; Hayirli et al., 2002; Matthews et al., 2012) and spend more time eating compared with high BCS cows (Tucker et al., 2007; Matthews et al., 2012); however, little is known about how BCS at calving interacts with a period of feed restriction after parturition to affect cow behavior and metabolism. It is possible that if low BCS cows cannot meet their nutritional requirements, their welfare is more likely to be impaired due to the continued depletion of body reserves.

The aim of this experiment was to determine how BCS at calving influences behavioral and physiological responses to a short-term feed restriction in lactating cows. Experimental groups of cows with a calving BCS of $3.4,4.6$, or 5.4 (on a 10-point scale; Roche et al., 2004) were created by modifying their diet during the previous lactation, and the response to a short-term feed restriction was investigated at 47 DIM, when nutrient requirements are high and pasture availability may be low in seasonal calving pasture-based systems. It was predicted that all cows would demonstrate behavioral and physiological responses to the feed restriction after parturition, but that cows with low calving BCS would demonstrate a more marked response.

\section{MATERIALS AND METHODS}

\section{Animals and Treatments}

All procedures involving animals in this study were approved by the Ruakura Animal Ethics Committee under the New Zealand Animal Welfare Act 1999. The current study was a part of a larger investigation aiming to explore the welfare of dairy cattle calving at BCS 3.5, 4.5, or 5.5. The study was undertaken at the DairyNZ Lye Farm, Hamilton, New Zealand $\left(37^{\circ} 76^{\prime}\right.$ S $175^{\circ} 37^{\prime} \mathrm{E}$ ). A group of 60 healthy (as determined by a veterinary clinical examination) cows without previous history of disease, including mastitis, and confirmed pregnancy status, were enrolled in the experiment on 1 February 2011.

Cows were allocated randomly to treatment groups (20 cows per group), ensuring treatments were balanced for age, breed, BCS at the time of enrolment, and expected calving date. Age at enrollment was $4.0 \pm$ 1.4 yr (mean $\pm \mathrm{SD}$ ). Mean expected calving date was 9 July \pm 9 d. Fourteen cows in each group were HolsteinFriesian, with the balance being $75 \%$ Holstein-Friesian and $25 \%$ Jersey-cross.

From 1 February, feeding levels were manipulated with the intention of generating 3 BCS groups before the end of lactation; target BCS at drying off was 5.0, 4.0, and 3.0 for the high, medium, and low groups, respectively (based on a 10-point scale, where 1 is emaciated and 10 obese; Roche et al., 2004). Following drying off (all cows had a minimum dry period of $60 \mathrm{~d}$ ), cows were offered pasture and supplements to allow for fetal growth and a gain of 0.5 BCS units before calving, with the intention that mean calving BCS would be $5.5,4.5$, and 3.5 , for the high, medium, and low groups, respectively. This would be equivalent to $3.3,2.9$, and 2.6 , respectively, in systems based on a 5-point scale (Roche et al., 2004).

During late lactation, daily feed allowances took into account the average BCS state of the group and the proposed trajectory of BCS change. Cows in the high, medium, and low treatments had an estimated daily DMI of fresh pasture of $12.3( \pm 3.38), 11.2( \pm 2.26)$, and $6.8( \pm 1.69) \mathrm{kg}$ of $\mathrm{DM}$, respectively. Maize and pasture silage, and rolled maize grain were provided to supplement DMI when pasture availability did not meet cow requirements. Allocated feed supplements were weighed, and estimations of wastage are included in the final calculation of DMI from these sources (Table 1). When an individual cow's BCS was not tracking toward the treatment target, she was moved to a group with a feeding regimen that facilitated the desired change. Groups grazed the same paddock with electric fences separating them. Mean pasture DMI was calculated as the product of the difference between the pre- and postgrazing pasture mass and area grazed on $3 \mathrm{~d} / \mathrm{wk}$, as outlined by Roche et al. (2005). Pasture and supplementary feed samples representative of what the cows were offered were collected and processed for quality analysis. Feed samples were oven-dried at $60^{\circ} \mathrm{C}$, ground to pass through a $0.5-\mathrm{mm}$ sieve (Christy Laboratory 
Table 1. Mean ( \pm SEM) estimated individual cow DMI of pasture and supplement, and total DMI (kg of DM/d) for 5 mo before calving; cows calved at BCS $^{1} 3.4$ (low), 4.6 (medium), and 5.4 (high)

\begin{tabular}{|c|c|c|c|c|c|c|c|c|c|c|c|c|c|}
\hline \multirow{2}{*}{$\begin{array}{l}\text { Month } \\
\text { relative } \\
\text { to calving }\end{array}$} & \multicolumn{3}{|c|}{ Low BCS } & \multicolumn{5}{|c|}{ Medium BCS } & \multicolumn{5}{|c|}{ High BCS } \\
\hline & Pasture & $\begin{array}{l}\text { Pasture } \\
\text { silage }\end{array}$ & Total & Pasture & $\begin{array}{l}\text { Pasture } \\
\text { silage }\end{array}$ & $\begin{array}{l}\text { Maize } \\
\text { silage }\end{array}$ & $\begin{array}{l}\text { Maize } \\
\text { grain }\end{array}$ & Total & Pasture & $\begin{array}{c}\text { Pasture } \\
\text { silage }\end{array}$ & $\begin{array}{l}\text { Maize } \\
\text { silage }\end{array}$ & $\begin{array}{l}\text { Maize } \\
\text { grain }\end{array}$ & Total \\
\hline 4 & $\begin{array}{l}5.7 \\
(0.92)\end{array}$ & $\begin{array}{l}2.8 \\
(0.84)\end{array}$ & $\begin{array}{l}8.5 \\
(1.15)\end{array}$ & $\begin{array}{l}12.1 \\
(2.79)\end{array}$ & $\begin{array}{l}5.1 \\
(0.50)\end{array}$ & - & $\begin{array}{l}1.4 \\
(1.01)\end{array}$ & $\begin{array}{l}18.6 \\
(2.48)\end{array}$ & $\begin{array}{l}14.3 \\
(2.81)\end{array}$ & $\begin{array}{c}4.7 \\
(0.46)\end{array}$ & - & $\begin{array}{c}3.1 \\
(0.76)\end{array}$ & $\begin{array}{l}22.1 \\
(3.04)\end{array}$ \\
\hline 2 & $\begin{array}{c}6.8 \\
(1.20)\end{array}$ & $\begin{array}{l}2.0 \\
(0.00)\end{array}$ & $\begin{array}{l}8.8 \\
(1.20)\end{array}$ & $\begin{array}{l}9.9 \\
(0.68)\end{array}$ & - & $\begin{array}{l}2.1 \\
(0.16)\end{array}$ & $\begin{array}{c}0.4 \\
(0.88)\end{array}$ & $\begin{array}{l}12.4 \\
(0.92)\end{array}$ & $\begin{array}{l}8.7 \\
(1.25)\end{array}$ & $\begin{array}{c}0.8 \\
(1.60)\end{array}$ & $\begin{array}{l}5.6 \\
(2.20)\end{array}$ & $\begin{array}{l}2.5 \\
(0.88)\end{array}$ & $\begin{array}{l}17.6 \\
(1.66)\end{array}$ \\
\hline 1 & $\begin{array}{c}6.8 \\
(1.69)\end{array}$ & $\begin{array}{l}1.9 \\
(1.03)\end{array}$ & $\begin{array}{l}8.7 \\
(1.27)\end{array}$ & $\begin{array}{l}10.0 \\
(1.11)\end{array}$ & $\begin{array}{l}1.2 \\
(1.10)\end{array}$ & $\begin{array}{c}0.7 \\
(0.95)\end{array}$ & - & $\begin{array}{l}11.9 \\
(1.25)\end{array}$ & $\begin{array}{l}7.5 \\
(0.33)\end{array}$ & $\begin{array}{c}3.6 \\
(3.29)\end{array}$ & $\begin{array}{c}3.2 \\
(4.39)\end{array}$ & $\begin{array}{l}2.0 \\
(0.00)\end{array}$ & $\begin{array}{l}16.3 \\
(0.90)\end{array}$ \\
\hline
\end{tabular}

${ }^{1}$ Ten-point scale (Roche et al., 2004).

Mill, Suffolk, UK), and sent for chemical analysis to Dairy One Forage Laboratory Services (Ithaca, NY). Estimated DMI ( $\mathrm{kg}$ of $\mathrm{DM} /$ cow per day) during the treatment preparation period are provided in Table 1 , with nutritional analyses presented in Table 2.

General management of the cows, including mineral and trace element supplementation, was in accordance with farm practice. From 30 May until calving, cows were supplemented with $\mathrm{Mg}$ via the water reticulation system (Dosatron Water Dispensers, Bell-Booth Ltd., Palmerston North, New Zealand) at a rate calculated to provide $10 \mathrm{~g}$ of elemental $\mathrm{Mg} / \mathrm{cow}$ per day. They also received an oral $\mathrm{Mg}$ supplement weekly as $\mathrm{Mg}$ pidolate, an organic chelate purported to provide $\mathrm{Mg}$ for 5 to $7 \mathrm{~d}$ (100 mL of More-Mag, Dominion Chemicals Ltd., Auckland, New Zealand). Following calving, cows received oral $\mathrm{Mg}$ salts, sufficient to provide $20 \mathrm{~g}$ of elemental $\mathrm{Mg} / \mathrm{cow}$ per day.

During calving, at $1300 \mathrm{~h}$ each day, cows that had calved between $1000 \mathrm{~h}$ the previous day and $1000 \mathrm{~h}$ the current day were collected from the pasture with their calves [except where cows had been observed hav-

Table 2. Mean ( \pm SEM) nutrient composition (percentage of DM, unless otherwise stated), macro-mineral concentration, trace-mineral $(\mathrm{mg} / \mathrm{kg}$ of DM) concentration, DCAD $(\mathrm{mEq} / 100 \mathrm{~g}$ of DM), 24-h in vitro total digestibility (IVTD), 24-h NDF digestibility (NDFD; percentage of NDF), ME (MJ/kg of DM), and DM of feeds offered throughout the experiment to generate the different BCS groups

\begin{tabular}{|c|c|c|c|c|}
\hline Item & Pasture & $\begin{array}{l}\text { Pasture } \\
\text { silage }\end{array}$ & $\begin{array}{l}\text { Maize } \\
\text { silage }\end{array}$ & Concentrate \\
\hline $\mathrm{CP}$ & $25.2(0.9)$ & $15.6(0.4)$ & 21.8 & 6.8 \\
\hline $\mathrm{ADF}$ & $27.3(1.1)$ & $38.1(0.5)$ & 22.3 & 22.5 \\
\hline NDF & $44.2(1.9)$ & $55.0(1.0)$ & 35.7 & 35.0 \\
\hline Lignin & $4.8(0.3)$ & $5.2(0.3)$ & 5.2 & 2.4 \\
\hline NFC & $24.2(1.8)$ & $17.6(1.2)$ & 34.5 & 51.7 \\
\hline Starch & $1.4(0.3)$ & $1.3(0.4)$ & 14.3 & 42.8 \\
\hline Crude fat & $4.0(0.2)$ & $4.1(0.2)$ & 5.7 & 3.0 \\
\hline Ash & $10.7(0.4)$ & $11.1(0.3)$ & 10.5 & 4.5 \\
\hline $\mathrm{Ca}$ & $0.74(0.05)$ & $0.55(0.02)$ & 0.70 & 0.16 \\
\hline $\mathrm{Cl}$ & $1.3(0.17)$ & $1.4(0.05)$ & 0.31 & 0.35 \\
\hline $\mathrm{Mg}$ & $0.24(0.02)$ & $0.18(0.003)$ & 0.29 & 0.10 \\
\hline $\mathrm{P}$ & $0.39(0.02)$ & $0.33(0.01)$ & 0.65 & 0.23 \\
\hline $\mathrm{K}$ & $3.4(0.09)$ & $2.8(0.1)$ & 0.87 & 1.11 \\
\hline $\mathrm{Na}$ & $0.20(0.02)$ & $0.16(0.01)$ & 0.28 & 0.02 \\
\hline S & $0.4(0.02)$ & $0.21(0.003)$ & 0.31 & 0.1 \\
\hline $\mathrm{Fe}$ & $94.5(6.4)$ & $578(83.3)$ & 1,048 & 242 \\
\hline $\mathrm{Zn}$ & $43.5(1.9)$ & $36.3(1.0)$ & 203 & 32 \\
\hline $\mathrm{Cu}$ & $8.2(0.7)$ & $7.0(0.9)$ & 24.5 & 6 \\
\hline $\mathrm{Mn}$ & $45(2.2)$ & $97.0(8.5)$ & 110 & 27 \\
\hline Мо & $1.1(0.2)$ & $1.2(0.1)$ & 1.4 & 0.35 \\
\hline DCAD & $33.2(4.5)$ & $26.8(1.8)$ & 6.5 & 13 \\
\hline IVTD & $82.5(2.3)$ & $76.7(0.8)$ & 75.5 & 77 \\
\hline NDFD & $61(4.1)$ & $57.7(1.6)$ & 31.5 & 35 \\
\hline $\mathrm{ME}$ & $12.0(0.4)$ & $11.1(0.1)$ & 10.8 & 11.1 \\
\hline DM (\% fresh) & & $29.6(6.6)$ & 34.1 & 90.1 \\
\hline
\end{tabular}


Table 3. Body condition score, BW, milk production, DIM, and age (mean \pm SD) of the dairy cattle used in the study

\begin{tabular}{lccc}
\hline Item & Low BCS & Medium BCS & High BCS \\
\hline No. & 17 & 18 & 20 \\
BCS $^{1}$ & $3.4 \pm 0.2$ & $4.6 \pm 0.2$ & $5.4 \pm 0.2$ \\
BCS $^{2}$ & $3.2 \pm 0.2$ & $3.7 \pm 0.2$ & $4.1 \pm 0.3$ \\
BW $^{2}(\mathrm{~kg})$ & $450 \pm 45.9$ & $465 \pm 44.5$ & $460 \pm 63.3$ \\
Milk production $^{2}(\mathrm{~kg} / \mathrm{d})$ & $23 \pm 4.0$ & $24 \pm 3.2$ & $24 \pm 3.8$ \\
DIM $^{2}(\mathrm{~d})$ & $46 \pm 3.1$ & $47 \pm 2.3$ & $47 \pm 2.6$ \\
Age $^{2}$ (yr) & $4 \pm 1.4$ & $5 \pm 1.3$ & $4 \pm 1.4$ \\
\hline
\end{tabular}

${ }^{1}$ At calving; 10-point system (Roche et al., 2004).

${ }^{2}$ At testing; 47 DIM.

ing calving difficulty $(\mathrm{n}=2)$ or milk fever $(\mathrm{n}=2)$, which were attended to immediately]. Collection day was designated as the day of calving. Cows were milked twice a day. They entered a colostrum herd for their first 10 milkings and were then transferred to the milking herd. Following transfer to the milking herd, cows were managed as a single group. Cows were offered a generous allowances of pasture $(>35 \mathrm{~kg}$ of DM/cow per day to ground level) and supplemented with pasture silage. No dietary manipulations of treatment groups were undertaken between calving and 47 DIM.

Five animals were removed from the group for reasons unrelated to the feeding regimen, leaving a total of 55 cows in the present study $(\mathrm{n}=20,18$, and 17 for the high, medium, and low BCS treatments, respectively). Features of these treatment groups are summarized in Table 3. To facilitate behavioral observations and ensure appropriate replication of groups, cows were subdivided into 4 groups based on calving date (3 groups with 14 cows and 1 group with 13 cows); all 3 treatments were present in each group. The 4 groups were tested consecutively in August and the first 2 wk in September 2011 (southern hemisphere spring) and were formed $3 \mathrm{~d}$ before the start of observations. The observation period started at $47 \pm 2.7$ DIM. Average air temperature (over $24 \mathrm{~h}$ ) for the experimental period was $8.7^{\circ} \mathrm{C}$ (ranging from -3.7 to $18.4^{\circ} \mathrm{C}$ ). Body weight and $\mathrm{BCS}$ were determined twice weekly following the morning milking or at approximately $0800 \mathrm{~h}$ by a minimum of 2 assessors. All assessors were trained and were recalibrated at the start of the experiment according to industry standard (Macdonald and Roche, 2004).

Cows were milked twice daily; at approximately 0700 and $1500 \mathrm{~h}$. A fresh allocation of pasture was provided daily immediately after the morning milking and silage was provided after the afternoon milking. Mean pasture DMI was calculated as the product of the difference between the pre- and postgrazing pasture mass and area grazed (Roche et al., 2005). Access to water was ad libitum at all times.

During habituation to their groups and during the first $2 \mathrm{~d}$ of observations, the groups were allocated 15 $\mathrm{kg}$ of $\mathrm{DM} /$ cow per day ( $100 \%$ feed allocation). After 2 $\mathrm{d}$ of baseline observations, cows were exposed to a feed challenge for $3 \mathrm{~d}$ consisting of $2 \mathrm{~d}$ of $11 \mathrm{~kg}$ of DM/cow per day (75\% feed allocation) and $1 \mathrm{~d}$ of $7.5 \mathrm{~kg}$ of DM/ cow per day ( $50 \%$ feed allocation). The ratio of grass to silage varied from day to day, depending on pasture availability. Following the $3 \mathrm{~d}$ of feed restriction, cows were offered $19 \mathrm{~kg}$ of DM/cow per day (125\% feed allocation) for $3 \mathrm{~d}$. Thus, each group was observed for $8 \mathrm{~d}$ in total. Estimated DMI is summarized in Table 4, with the nutritional profile in Table 5 (for August only).

All cows received a vaginal controlled internal drug release insert (Pfizer, Auckland, NZ) during the experimental period (releasing $1.38 \mathrm{~g}$ of progesterone per cow) to avoid the confounding effects of estrus on behavioral observations. The controlled internal drug release inserts were inserted into the vaginal cavity on the day of the first observation (before morning milk-

Table 4. Estimated pasture and silage DMI ( \pm SD) during the 8-d measurement period for dairy cows (4 groups) provided with different feed allocations (d 1-8) at $47 \mathrm{DIM}^{1}$

\begin{tabular}{lrrr}
\hline Day & Pasture & Silage & \multicolumn{1}{c}{ Total } \\
\hline $1-2(100 \%)$ & $11.9 \pm 0.9$ & $4.3 \pm 1.7$ & $16.2 \pm 1.3$ \\
$3-4(75 \%)$ & $11.0 \pm 1.3$ & $2.7 \pm 0.9$ & $13.7 \pm 0.7$ \\
$5(50 \%)$ & $8.0 \pm 9.8$ & $1.9 \pm 0.9$ & $9.8 \pm 1.4$ \\
$6-8(125 \%)$ & $13.1 \pm 2.2$ & $5.6 \pm 3.6$ & $18.6 \pm 1.5$ \\
\hline
\end{tabular}

${ }^{1}$ Feed allocation was $125,100,75$, or $50 \%$ of $15 \mathrm{~kg}$ of DM/cow per day. 
Table 5. Mean nutrient composition (percentage of DM, unless otherwise stated), macro-mineral concentration, trace-mineral (mg/ $\mathrm{kg}$ of $\mathrm{DM})$ concentration, DCAD (mEq/100 $\mathrm{g}$ of $\mathrm{DM}), 24$-h in vitro total digestibility (IVTD), 24-h NDF digestibility (NDFD; percentage of $\mathrm{NDF}$ ), and $\mathrm{ME}(\mathrm{MJ} / \mathrm{kg}$ of $\mathrm{DM})$ of pasture and pasture silage offered during the first $4 \mathrm{wk}$ of the observation period

\begin{tabular}{lcc}
\hline Item & Pasture & $\begin{array}{c}\text { Pasture } \\
\text { silage }\end{array}$ \\
\hline CP & 24.3 & 14.4 \\
ADF & 21.9 & 39.0 \\
NDF & 34.5 & 57.4 \\
Lignin & 3.5 & 4.8 \\
NFC & 35.3 & 15.6 \\
Starch & 0.8 & 0.9 \\
Crude fat & 4 & 3.6 \\
Ash & 8.8 & 11.6 \\
Ca & 0.5 & 0.48 \\
P & 0.43 & 0.31 \\
Mg & 0.15 & 0.17 \\
K & 3.14 & 2.96 \\
Na & 0.11 & 0.16 \\
Fe & 102 & 694 \\
Zn & 34 & 35 \\
Cu & 5 & 6 \\
Mn & 46 & 104 \\
Mo & 2.3 & 0.9 \\
S & 0.31 & 0.2 \\
Cl & 0.73 & 1.53 \\
DCAD & 45 & 27 \\
IVTD & 93 & 74 \\
NDFD & 80 & 54 \\
ME & 13.8 & 10.6 \\
\hline
\end{tabular}

ing) and removed immediately after the eighth day of observations.

\section{Behavior}

Time budgets for lying, standing, eating silage, grazing, and ruminating were estimated using instantaneous scan sampling (Martin and Bateson, 1993) every $10 \mathrm{~min}$ from 0840 to $1810 \mathrm{~h}$ (excluding p.m. milking) on all $8 \mathrm{~d}$ of data collection for each group. In addition, 24-h observations (excluding milkings) were undertaken on d 1 (100\% feed allocation) and on the first day of the $125 \%$ feed allocation (d 6). Cows were considered lying if their flank was in contact with the ground and standing otherwise. Cows were considered grazing if pasture was being ingested or could be seen in the mouth. Similarly, cows were considered eating silage if silage was being ingested or could be seen in the mouth. An animal was considered ruminating if the cow was performing chewing movements without any feed observed in the mouth. Individual cows were identified with ear tags and paint on the rump (Tell tail paint, FIL NZ Ltd., Mount Maunganui, New Zealand).

Before the fresh sward of pasture was provided after morning milking, cows were held back on the previous day's grazed pasture for $10 \mathrm{~min}$, during which time the number of vocalizations per cow was recorded, follow- ing the definitions of Rushen et al. (1999). Aggressive interactions were recorded during $15 \mathrm{~min}$ immediately before afternoon milking in a competitive feeding situation. Each group was kept in a small enclosure $(22 \times 6$ $\mathrm{m})$ close to the milking parlor, with a feed trough (0.4 $\times 0.9 \times 4.0 \mathrm{~m}$, depth by width by length) containing a small proportion of the daily silage ration, such that it could be consumed within 15 min. The feed trough was only accessible from one side, thus $0.4 \mathrm{~m}$ of feeding space was allotted per cow. An aggressive interaction was defined as a rapid, forceful physical contact between the head of a cow (the instigator, poll had to be above the feed trough) and another cow. The identification of the instigator, but not the receiving cow, was recorded. A single observer watched 1 group of cows at any given time for time budgets and vocalizations. Two observers recorded aggressive interactions (half the trough each). Over the course of the study, multiple observers were used to collect the behavioral information from all groups. Interobserver reliability for the time budget observations, as measured by percentage agreement, was between 99 and $100 \%$ for all behaviors. The interobserver reliability for vocalizations and aggressive interactions, as measured by correlation, was $0.98 \pm 0.034$ and $0.92 \pm 0.100$, respectively.

\section{Physiology}

Cows were blood sampled daily, before morning milking, by coccygeal venepuncture into a plain evacuated tube (Vaccutainer, Becton Dickinson, Franklin Lakes, NJ) for analysis of serum concentrations of leptin, BHBA, and NEFA. Samples were held at ambient temperature following collection for up to $5 \mathrm{~h}$ to allow clotting and then centrifuged at $1,500 \times g(\sim 3,000 \mathrm{rpm})$ for $12 \mathrm{~min}$ at ambient temperature, serum aspirated, and aliquots stored at $-20^{\circ} \mathrm{C}$ until assayed. Samples for metabolite assays were analyzed using colorimetric techniques performed on a Hitachi Modular P800 analyzer at $37^{\circ} \mathrm{C}$ (Roche Diagnostics, Indianapolis, IN) by Gribbles Veterinary Pathology Ltd. (Hamilton, New Zealand). Roche reagent kits were used to measure BHBA (interassay $\mathrm{CV}=4.5 \%$; intra-assay $\mathrm{CV}=$ $1.4 \%)$. Leptin was analyzed using a Millipore Multispecies Leptin RIA kit (Merck Millipore, Billerica, MA; interassay $\mathrm{CV}=6.1 \%$ at $3.9 \mathrm{ng} / \mathrm{mL}$ and $4.2 \%$ at 14.2 $\mathrm{ng} / \mathrm{mL}$; intra-assay $\mathrm{CV}=5.75 \%$ and $4.15 \%$ at $3.9 \mathrm{ng} /$ $\mathrm{mL}$ and $14.2 \mathrm{ng} / \mathrm{mL}$, respectively) to investigate treatment differences rather than absolute values, as this kit may underestimate leptin concentrations in cattle (Ehrhardt et al., 2000). Serum NEFA were analyzed using WAKO Diagnostics (VA) kit (HR2; Wako Pure Chemical Industries Ltd., Osaka, Japan; interassay CV $=5.1 \%$; intra-assay $\mathrm{CV}=0.5 \%$ ). 
At the time of blood collection, fecal samples were collected by rectal grab, immediately placed on ice and then stored at $-20^{\circ} \mathrm{C}$ until extraction and analysis for glucocorticoid metabolite concentrations. The samples were analyzed using a commercially available EIA kit. The cross-reactivities for the antiserum (CJM06; Coralie Munro, Clinical Endocrinology Laboratory, University of California, Davis) were corticosterone $(100 \%)$, desoxycorticosterone $(14.25 \%)$, tetrahydrocorticosterone $(0.9 \%)$, cortisol $(0.23 \%)$, 11-deoxycortisol $(0.03 \%)$, and cortisone $(<0.01 \%)$. Sensitivity of the corticosterone enzyme immunoassay was $7.8 \mathrm{pg} /$ well. Intra- and interassay $\mathrm{CV}$ for the analysis were $<12 \%$. All fecal data are expressed on a DM basis (i.e., ng of immunoreactive corticosterone/g of DM of feces). In addition, individual milk production was recorded daily throughout the 8-d experimental period using the Westfalia Surge milking system and its associated Dairy Plan C21 herd and parlor management software (GEA Farm Technologies, Cambridge, New Zealand).

\section{Statistical Analysis}

Behavior. Daily observations between 0840 and $1810 \mathrm{~h}$ were averaged per animal per day and analyzed using a repeated measures REML analysis with BCS treatment [calving BCS; 2 degrees of freedom (df)], group (3 df), day ( $7 \mathrm{df})$, and their interactions as fixed effects and animal as the random effect. The analysis was undertaken with a uniform covariance structure (no serial correlation was evident). Variation between BCS at calving and testing were accounted for by calculating the difference between testing and assigned BCS $(3.5,4.5$, or 5.5 , respectively). These BCS deviations were included in the models as covariates. In addition, an ANOVA was used to test each day separately; this analysis also included covariates. Data averaged over 24 $\mathrm{h}$ for $\mathrm{d} 1$ and $\mathrm{d} 6$ were also analyzed using an ANOVA without covariates.

A generalized linear mixed model (GLMM) analysis with binomial distribution (whether or not an animal showed any aggressive interactions or vocalizations) was used to analyze aggression and vocalization data; due to a large number of zero values, it was not possible to analyze the actual number of aggressive behaviors or vocalizations. Treatment BCS (2 df), group (3 df), day $(7 \mathrm{df})$, and their interactions were used as fixed effects and animal as the random effect. The analysis was done with a standard uniform correlation structure. Age had a significant effect on aggression; thus, age was added to the analysis as a covariate. Each day was also analyzed independently using a GLM with binomial distribution with age as a covariate for aggressive interactions.
Physiology and Milk Production. Concentrations of NEFA, BHBA, leptin, and corticosterone, as well as milk yield, were analyzed using the same models as for time budgets. All NEFA and corticosterone values required log-transformation before analysis; backtransformed data are presented. Data from 1 low, 3 medium, and 2 high BCS cows were excluded from the corticosterone analysis due to extraction failure.

In addition, an ANOVA without covariates was used to compare BCS of the treatment groups at the time of testing. All statistical analyses in this study were conducted using the statistical package GenStat, version 13.2 (VSN International, Hemel Hempstead, UK).

\section{RESULTS}

All treatment groups lost BCS between calving and time of testing; however, the BCS of the groups was statistically different at the time of testing $(P<0.001$; Table 3).

\section{Behavior}

Daytime time budgets for grazing, eating silage, ruminating, standing, and lying for each day (daytime: 0840 to $1810 \mathrm{~h}$ ) of the experiment are presented in Figure 1. All behaviors changed in response to feed restriction, (effect of day, $P<0.001$ ); however, no interaction between BCS and day $(P \geq 0.461)$ was observed. In general, all cows responded to the feed restriction with an increase in time spent both grazing and eating silage, and a decrease in time spent lying and ruminating (Figure 1). Although, in general, cows responded similarly to feed restriction, a few exceptions were noted. When days were considered separately, high BCS cows spent $4 \%$ more time standing without eating on d $2[100 \%$ feed allocation; standard error of difference (SED) $=$ $1.7 \% ; P=0.021]$, whereas low BCS cows spent $3 \%$ more time ruminating on d 6 (the first day of $125 \%$ feed allocation; $\mathrm{SED}=1.6 \% ; P=0.088)$. No other evidence of any behavioral differences between the BCS groups during the daytime recordings was observed when days were considered separately $(P \geq 0.181)$.

The results for the 24-h observations undertaken on the first day of $100 \%$ feed allocation (d 1) and the first day of $125 \%$ feed allocation (d 6) are presented in Table 6. On d 1, low BCS cows spent $2 \%$ more time eating silage than the other 2 groups $(P=0.070)$. On $\mathrm{d} 6$, medium-BCS cows spent $2 \%$ more time grazing than the other groups $(P=0.023)$. No other effects of BCS on behavior were observed during the 24 -h observations $(P \geq 0.136)$.

The proportion of cows engaged in aggressive interactions is presented in Figure 2. Feed restriction af- 
a)
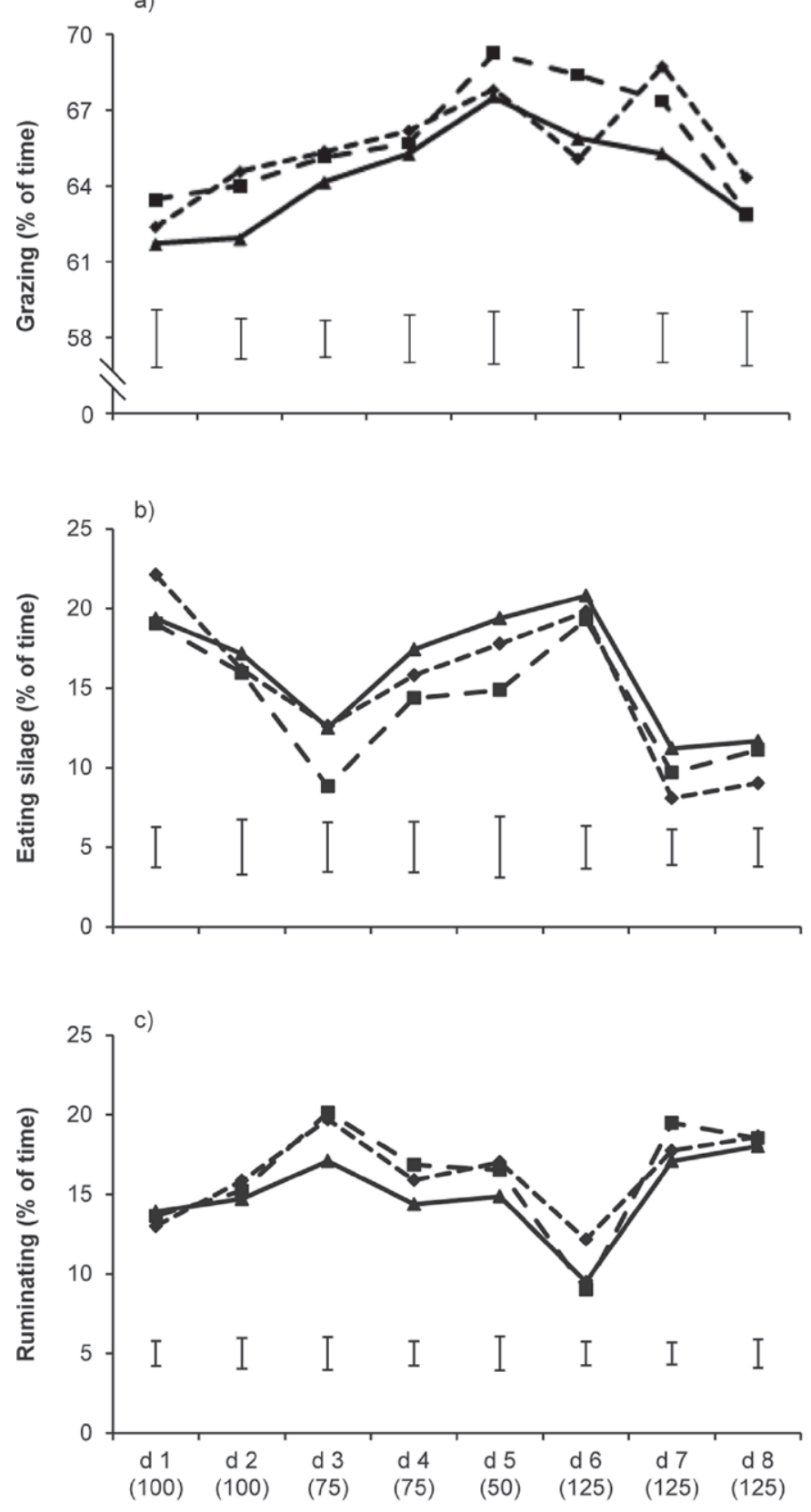
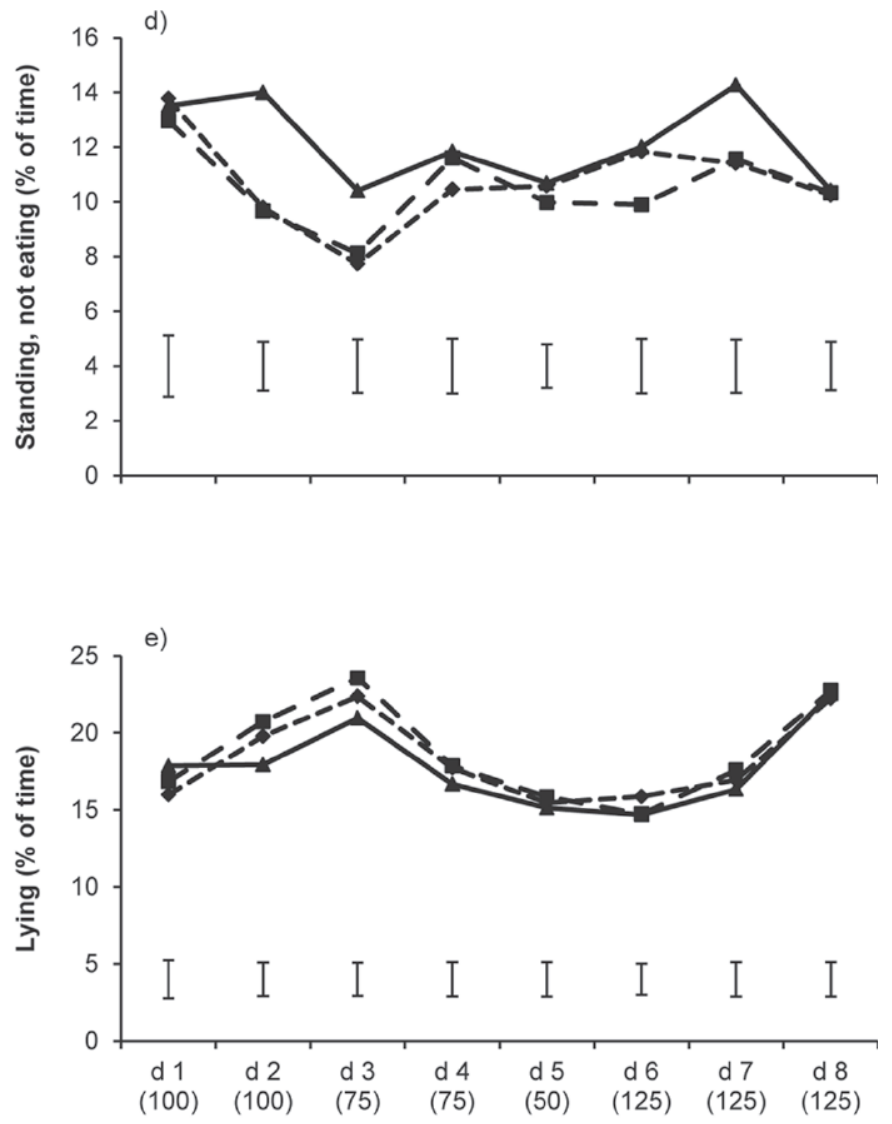

Treatment day (d) and feed allocation (\%)

Treatment day (d) and feed allocation (\%)

Figure 1. Effect of calving BCS [low $(\diamond): 3.4, \mathrm{n}=17$; medium $(\boldsymbol{\square})$ : 4.6, $\mathrm{n}=18$; high $(\boldsymbol{\Delta}): 5.4, \mathrm{n}=20$ ] on percent time $( \pm$ standard error of difference) spent grazing (a), eating silage (b), ruminating (c), standing without eating (d), and lying (e) at 47 DIM and on days with different feed allocation (percentage of feed allocation on the x-axis). Behavior was measured 0840 to $1810 \mathrm{~h}$ (excluding p.m. milking) each day.

fected aggressive behavior (effect of day, $P=0.042$ ); a greater proportion of cows were aggressive during the feed-restriction period (d 3 to 5) and during the first day of baseline observations (d 1) than on the other observation days. However, no overall interaction between BCS and day of trial $(P=0.136)$ was observed; similar proportions of cows in the different BCS groups were aggressive toward other cows at the feed trough $(P \geq$
0.208). When days were considered separately, a lower proportion of low BCS cows was aggressive at the feed trough on the first day of feed restriction (d 3); $32 \%$ of cows with low BCS engaged in at least 1 aggressive interaction, compared with 74 and $64 \%$ of medium and high BCS, respectively (SED $=15.4 \% ; P=0.035$ ).

The proportion of cows that vocalized in anticipation of feed is presented in Figure 3. All groups vocalized 
Table 6. Effect of calving BCS (low: 3.4, $\mathrm{n}=17$; medium: 4.6, $\mathrm{n}=18$; high: $5.4, \mathrm{n}=20$ ) on percent of time $(24 \mathrm{~h})$ spent grazing, eating silage, ruminating, standing without eating, and lying [LSM and standard error of difference (SED)] when cows were provided with either $100 \%$ feed allocation (15 kg of DM/cow; d 1) or $125 \%$ allocation (19 kg of DM/cow; d 6) before and after a 3 -d feed restriction ${ }^{1}$

\begin{tabular}{lcccccc}
\hline Item & Day & Low & Medium & High & SED & P-value \\
\hline Grazing (\%) & 1 & 30 & 32 & 31 & 1.3 & 0.447 \\
Eating silage (\%) & 6 & 36 & 38 & 36 & 1.0 & 0.023 \\
Ruminating (\%) & 1 & 7 & 5 & 6 & 0.9 & 0.070 \\
& 6 & 8 & 7 & 7 & 0.9 & 0.368 \\
Standing, not eating (\%) & 1 & 42 & 41 & 39 & 1.2 & 0.136 \\
Lying (\%) & 6 & 39 & 39 & 38 & 1.2 & 0.296 \\
& 1 & 22 & 26 & 25 & 2.7 & 0.366 \\
& 6 & 19 & 22 & 22 & 2.3 & 0.321 \\
& 1 & 42 & 38 & 40 & 2.9 & 0.393 \\
\hline
\end{tabular}

${ }^{1}$ Feed restriction consisted of $2 \mathrm{~d}$ of $75 \%$ and $1 \mathrm{~d}$ of $50 \%$ of $15 \mathrm{~kg}$ of DM/cow per day.

more after the first full day of feed restriction (effect of day; $P=0.029$ ); however, no interaction between BCS and day $(P=0.414)$ was observed. Calving BCS did not influence the proportion of cows that vocalized in anticipation of access to their daily pasture provision, either overall $(P=0.814)$ or when days were considered separately $(P \geq 0.106)$.

\section{Physiology}

Serum metabolite concentrations for BHBA, NEFA, and leptin are presented in Figure 4. Average serum BHBA concentration was 0.41 (ranging from 0.20-0.76), 0.42 (ranging from $0.25-0.69$ ), and $0.48 \mathrm{mmol} / \mathrm{L}$ (ranging from 0.25-0.92) for low-, medium-, and high BCS cows, respectively. Cows with a high calving BCS had higher serum BHBA concentrations $(P=0.001)$. Serum BHBA concentrations differed with day of trial $(P<$ 0.001), with concentrations higher after the 3-d feed restriction. An interaction between BCS and day $(P<$ 0.001) was also observed; cows with a high calving BCS had higher BHBA concentrations on d $1(P=0.077)$, d $3(P=0.019)$, d $4(P=0.040)$, and on d $6(P<0.001)$.

Average serum NEFA concentration was 0.14 (ranging from 0.05-0.68), 0.21 (ranging from 0.06-0.72), and $0.34 \mathrm{mmol} / \mathrm{L}$ (ranging from $0.09-0.91$ ) for low-, medium-, and high BCS cows, respectively. Cows with a high calving BCS also had higher serum NEFA concentrations overall $(P<0.001)$ and on all days when analyzed separately $(P<0.001)$. Concentrations differed on different days of the trial $(P<0.001)$; however, no interaction between BCS and day $(P=0.156)$ was

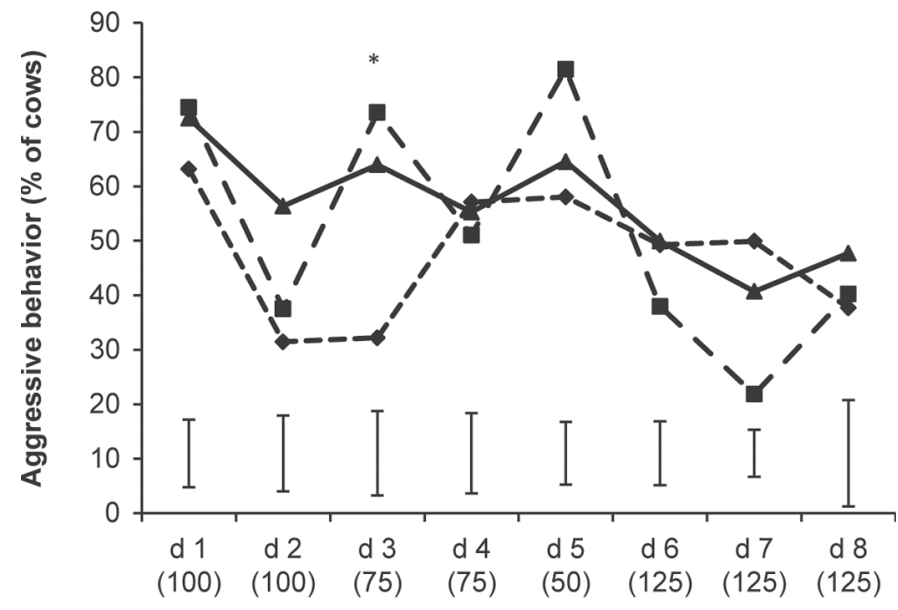

Treatment day (d) and feed allocation (\%)

Figure 2. Mean proportion ( \pm standard error of difference) of cows with different calving BCS [low $(\bullet): 3.4, \mathrm{n}=17$; medium $(\mathbf{\square}): 4.6, \mathrm{n}$ $=18$; high $(\mathbf{\Lambda}): 5.4, \mathrm{n}=20$ ] engaged in aggressive interactions at a feed trough. Testing was undertaken at 47 DIM and on days with different feed allocation (percentage of feed allocation on the x-axis). An asterisk $\left(^{*}\right)$ denotes a $P$-value $<0.05$.

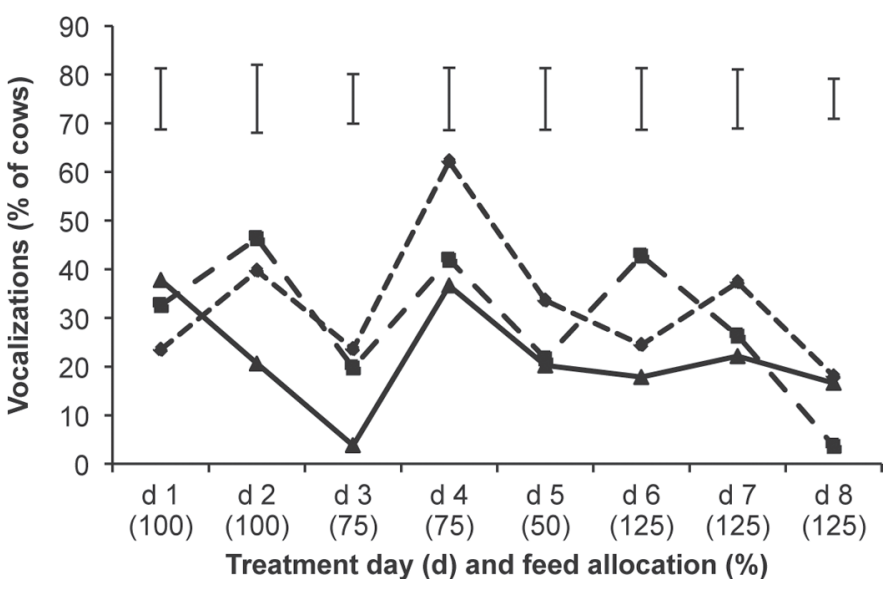

Figure 3. Effect of calving BCS [low $(\diamond): 3.4, \mathrm{n}=17$; medium $\mathbf{\square}): 4.6, \mathrm{n}=18$; high $(\boldsymbol{\Lambda}): 5.4, \mathrm{n}=20$ ] on vocalizations (percentage of cows vocalizing \pm standard error of difference), during 10 min in anticipation of new feed. Testing was undertaken at 47 DIM on days with different feed allocation (percentage of feed allocation on the $\mathrm{x}$ axis). Note that the recording of vocalizations was undertaken before the feed provision on each day. 

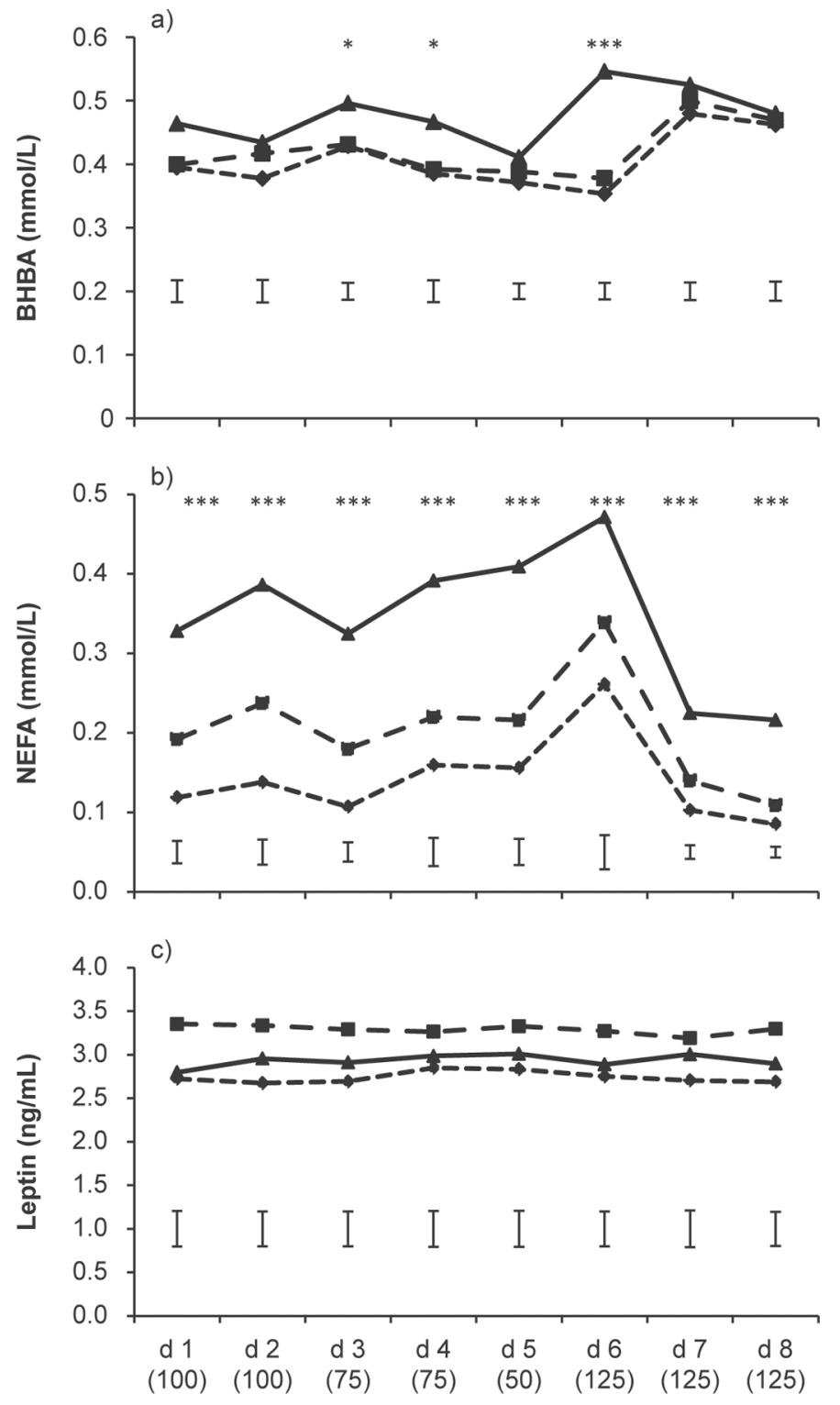

Figure 4. Effect of calving BCS [low $(\bullet): 3.4, \mathrm{n}=17$; medium ): 4.6, $\mathrm{n}=18$; high $(\mathbf{\Delta}): 5.4, \mathrm{n}=20]$ on serum BHBA (a), NEFA (b; back-transformed values), and leptin (c) concentrations. Sampling was undertaken at 47 DIM and on days with different feed allocation (percentage of feed allocation on the $\mathrm{x}$-axis). Values are means \pm standard error of difference. An asterisk $(*)$ denotes a $P$-value $<0.05$, three asterisks $(* * *)$ denotes a $P$-value $<0.001$. Note that the blood sampling was undertaken before the feed provision on each day.

observed. Serum NEFA concentrations were highest for all groups after the 3-d feed restriction period.

Cows with different calving BCS had similar serum leptin concentrations overall $(P=0.456)$ and when days were considered separately $(P \geq 0.305)$. Leptin concentrations were similar on all days of the trial $(P=$ $0.134)$ and no interaction between BCS and day $(P=$ 0.289 ) were observed. Average serum leptin concentra- tion was 2.8 (ranging from 1.7-6.7), 3.3 (ranging from $1.5-7.4$ ), and $3.0 \mathrm{ng} / \mathrm{mL}$ (ranging from 1.5-5.7) for low-, medium-, and high BCS cows, respectively.

Cows with different calving BCS also had similar concentrations of corticosterone, both overall $(P=$ 0.244 ) and on most days of the experiment. Low BCS cows had lower corticosterone concentrations after the $2 \mathrm{~d}$ of baseline observations than the other 2 groups $(P=0.067$; Figure 5$)$, but concentrations were similar on all other days $(P \geq 0.114)$. Average corticosterone concentration was 167.6 (ranging from 82.3-384.3), 200.0 (ranging from 85.3-476.9), and $179.7 \mathrm{ng} / \mathrm{g}$ (ranging from 62.0-383.4) for low-, medium-, and high BCS cows, respectively. Corticosterone concentrations differed with time $(P<0.001)$; however, no interaction between BCS and day $(P=0.625)$ was observed. Values were lowest on d 5 (after the 2 d of $75 \%$ feed allocation) and highest on d 7 (after the first day of $125 \%$ feed allocation).

\section{Milk Production}

Milk production was similar between the 3 BCS groups $(P=0.430$; Figure 6$)$ on all days throughout the experimental period. Milk production started to decline on the second day of feed restriction, and increased again on the third day of $125 \%$ feed allocation (effect of day; $P<0.001$ ); however, no interaction between BCS and day $(P=0.800)$ was observed.

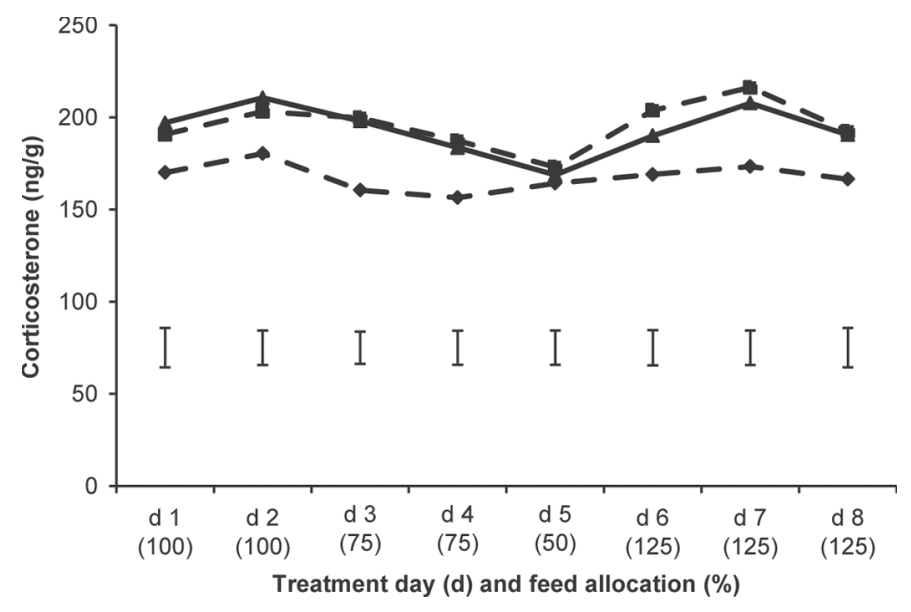

Figure 5. Effect of calving BCS [low $(\downarrow)$ : $3.4, \mathrm{n}=17$; medium $(\mathbf{\square})$ : $4.6, \mathrm{n}=18$; high $(\mathbf{\Lambda}): 5.4, \mathrm{n}=20$ ] on fecal corticosterone concentrations (ng/g of DM feces). Testing was undertaken at 47 DIM on days with different feed allocation (percentage of feed allocation on the $\mathrm{x}$ axis). Values are means \pm standard error of difference. Note that the fecal sampling was undertaken before the feed provision on each day. 


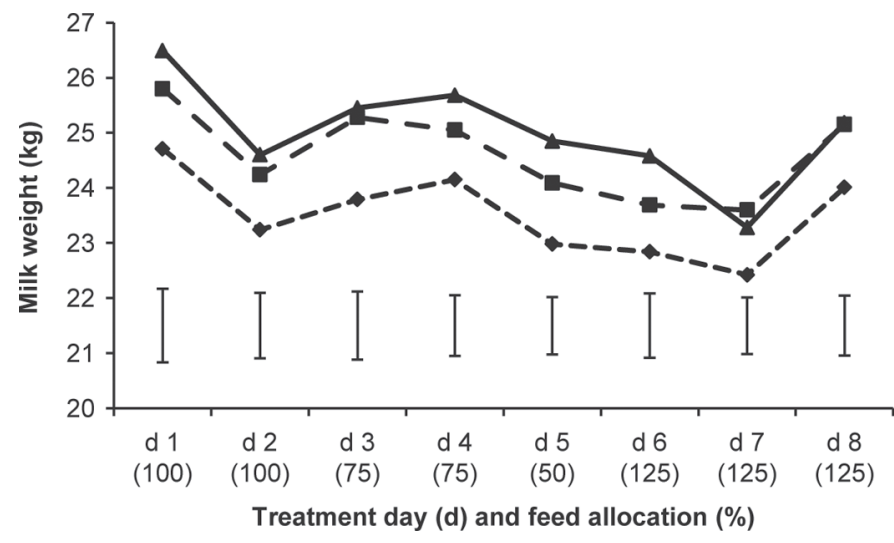

Figure 6. Daily milk weight $(\mathrm{kg})$ of dairy cattle with different calving BCS [low ( ): 3.4, $\mathrm{n}=17$; medium $(\boldsymbol{\square}): 4.6, \mathrm{n}=18$; high $(\boldsymbol{\Delta}): 5.4$, $\mathrm{n}=20]$. Testing was undertaken at 47 DIM and on days with different feed allocation (percentage of feed allocation on the $\mathrm{x}$-axis). Values are means \pm standard error of difference.

\section{DISCUSSION}

All cows responded behaviorally and physiologically to a short-term feed restriction at 47 DIM. Differences in calving BCS created by modifying the diet of healthy cows during the previous lactation had only minor effects on these responses. No evidence was observed to indicate that low BCS cows responded differently than other groups.

Cattle responded to the short-term feed restriction by spending more time grazing and eating silage, regardless of BCS at calving. These results agree with the general response to low herbage height (Phillips and Hecheimi, 1989; Gibb et al., 1999; Rook, 2005) and to feed restriction (Tucker et al., 2009), but differ from other work examining the overall feeding patterns of low BCS cattle. Previous research indicated that low BCS cows spent more time eating silage when it was offered ad libitum (Tucker et al., 2007), grazing, and had higher DMI (Hayirli et al., 2002; Matthews et al., 2012). These results indicate that low BCS cows may be experiencing greater feeding motivation (i.e., the motivation to obtain feed) than cows with higher BCS; however, this was not confirmed in the present study, where only weak evidence was observed for low BCS cows spending more time eating silage and ruminating during either unrestricted or restricted feeding conditions. It should be noted; however, that longer grazing times cannot necessarily be interpreted as the animals feeling hungry or consuming more feed, as bite rate and bite size can be modified depending on feed availability and other factors (Dougherty et al., 1989). Feeding rate was not measured in the current study, and we encourage future studies including this measure when exploring feeding motivation in cattle.
Other behavioral changes have also been used to assess feeding motivation. Aggressive interactions and cow vocalizations have been suggested as indirect measures of what animals are feeling and hunger levels (Thomas et al., 2001; Haley et al., 2005; Valizaheh et al., 2008; D'Eath et al., 2009). Although the present results agree with others that pasture-based dairy cattle increase vocalizations in response to feed restriction (Tucker et al., 2009), no effect of BCS on vocalizations was observed in anticipation of feed. In the current study, fewer than half the cows from the low BCS group displayed aggressive interactions at the feed trough on the first day of feed restriction, compared with the other 2 groups; this further suggests that low BCS cows were not experiencing greater feeding motivation as compared with cows with higher body condition. However, the results indicate that cows with a lower BCS may be less likely to get access to a feed source if the resource is limited by bunk space. Further research in this area is warranted.

The behavioral results are supported by physiological changes. No differences in corticosterone concentrations between the BCS groups in the current study (detectable on the $5 \%$ significance level); however, low BCS cows had numerically lower concentrations, which agrees with other studies (Tucker et al., 2007). Corticosterone concentrations differed on different days of the trial, but the fluctuations throughout the study period were minor. The findings agree with those of Fisher et al. (2002), where a moderate feed restriction (3 versus $4 \%$ of BW of DM) for $7 \mathrm{~d}$ did not influence fecal corticosteroid metabolites in Jersey cattle.

Circulating concentrations of BHBA and NEFA increased in all BCS groups after the 3-d feed restriction period, in agreement with other studies of cows exposed to varying periods of underfeeding (Delavaud et al., 2002; Roche, 2007; Chagas et al., 2008; Laeger et al., 2012). High BCS cows had higher concentrations of both metabolites, which indicates a greater propensity and ability to mobilize fat to maintain energetic homeostasis (however, BCS did not influence leptin concentrations). These results agree with reports that high BCS cows have sustained elevated plasma NEFA concentrations postpartum compared with cows with lower BCS (Holtenius et al., 2003; Lacetera et al., 2005).

As expected, a decrease in milk production was evident after $2 \mathrm{~d}$ of feed restriction. This is consistent with the results reported by Roche (2007), wherein restricting pasture allowance ( $8.6 \mathrm{~kg}$ of $\mathrm{DM} / \mathrm{cow}$ per day) for early lactation dairy cows reduced milk production. However, no interaction was noted with BCS, suggesting the greatest contribution of calving BCS to milk production occurs in the first few weeks of lactation (Roche et al., 2007b; unpublished data). 
The lack of interaction between BCS and treatment day throughout this study suggests that BCS at calving did not influence the overall behavioral or physiological response of the cows to the feed restriction period at 47 DIM. Several possible explanations exist for this. Roche et al. (2009) reported an insensitivity of BCS change to nutritional intervention in the first $30 \mathrm{DIM}$ and it is possible that cows adjust their postcalving BCS change or milk production to their current BCS, thereby overcoming any potential negative effects. Second, although $\mathrm{BCS}$ at the time of testing remained significantly different between the BCS groups, the differences in BCS between the treatment groups were less marked than at calving. It is possible that the detectable biological difference between different BCS may be low, so a larger sample size may be needed. For example, Matthews et al. (2012) reported a difference in grazing and lying behavior of 0.8 and $1.4 \%$ over $24 \mathrm{~h}$ per change in BCS, respectively, thus indicating that potential differences between cows at different BCS may be difficult to detect unless the extremes of BCS are studied.

\section{CONCLUSIONS}

All cows demonstrated marked behavioral and physiological responses to feed restriction; however, overall, behavioral and physiological changes were similar across BCS categories. No effect of calving BCS on these responses was observed.

\section{ACKNOWLEDGMENTS}

We are grateful to the technical assistance from AgResearch (Francis Huddart, Gemma Lowe, Gemma Worth, Stephanie Delaney, and Suzanne Dowling) and DairyNZ (Bruce Sugar, Lief Tumai, Jennie Burke, John Milburn, Sarah Taukiri, and Stuart Morgan) staff who participated in this work. This work was funded by New Zealand dairy farmers through DairyNZ Inc. (Hamilton, New Zealand, Contract no. AW807) and by the Ministry of Business, Innovation and Employment (Wellington, New Zealand, Contract no. C10X0813).

\section{REFERENCES}

Agenäs, S., K. Dahlborn, and K. Holtenius. 2003. Changes in metabolism and milk production during and after feed deprivation in primiparous cows selected for different milk fat content. Livest. Prod. Sci. 83:153-164.

Broster, W. H., and V. J. Broster. 1998. Body score of dairy cows. J. Dairy Res. 65:155-173.

Chagas, L. M., P. J. S. Gore, G. Graham, K. A. Macdonald, and D. Blache. 2008. Effect of restricted feeding and monopropylene glycol postpartum on metabolic hormones and postpartum anestrus in grazing dairy heifers. J. Dairy Sci. 91:1822-1833.

Chelikani, P. K., J. D. Ambrose, D. H. Keisler, and J. J. Kennelly. 2004. Effect of short-term fasting on plasma concentrations of leptin and other hormones and metabolites in dairy cattle. Domest. Anim. Endocrinol. 26:33-48.

D'Eath, R. B., B. J. Tolkamp, I. Kyriazakis, and A. B. Lawrence. 2009. 'Freedom from hunger' and preventing obesity: The animal welfare implications of reducing food quantity or quality. Anim. Behav. 77:275-288.

Delavaud, C., A. Ferlay, Y. Faulconnier, F. Bocquier, G. Kann, and Y. Chilliard. 2002. Plasma leptin concentration in adult cattle: Effects of breed, adiposity, feeding level, and meal intake. J. Anim. Sci. 80:1317-1328.

DeVries, T. J., M. A. G. von Keyserlingk, and D. M. Weary. 2004 Effect of feeding space on the inter-cow distance, aggression, and feeding behavior of free-stall housed lactating dairy cows. J. Dairy Sci. 87:1432-1438.

Dougherty, C. T., N. W. Bradley, P. L. Cornelius, and L. M. Lauriault. 1989. Short-term fasts and the ingestive behaviour of grazing cattle. Grass Forage Sci. 44:295-302.

Ehrhardt, R. A., R. M. Slepetis, J. Siegal-Willott, M. E. van Amburgh, A. W. Bell, and Y. R. Boisclair. 2000. Development of a specific radioimmunoassay to measure physiological changes of circulating leptin in cattle and sheep. J. Endocrinol. 166:519-528.

Fisher, A. D., G. A. Verkerk, C. J. Morrow, and L. R. Matthews. 2002. The effects of feed restriction and lying deprivation on pituitary-adrenal axis regulation in lactating cows. Livest. Prod. Sci. $73: 255-263$.

Frood, M. J., and D. Croxton. 1978. The use of condition-scoring in dairy cows and its relationship with milk yield and live weight. Anim. Prod. 27:285-291.

Gearhart, M. A., C. R. Curtis, H. N. Erb, R. D. Smith, C. J. Sniffen, L. E. Chase, and M. D. Cooper. 1990. Relationship of changes in condition score to cow health in Holsteins. J. Dairy Sci. 73:31323140 .

Gibb, M. J., C. A. Huckle, R. Nuthall, and A. J. Rook. 1999. The effect of physiological state (lactating or dry) and sward surface height on grazing behaviour and intake by dairy cows. Appl. Anim. Behav. Sci. 63:269-287.

Haley, D. B., D. W. Bailey, and J. M. Stookey. 2005. The effects of weaning beef calves in two stages on their behavior and growth rate. J. Anim. Sci. 83:2205-2214.

Hayirli, A., R. R. Grummer, E. V. Nordheim, and P. M. Crump. 2002. Animal and dietary factors affecting feed intake during the prefresh transition period in Holsteins. J. Dairy Sci. 85:3430-3443.

Heuer, C., Y. H. Schukken, and P. Dobbelaar. 1999. Postpartum body condition score and results from the first test day milk as predictors of disease, fertility, yield, and culling in commercial dairy herds. J. Dairy Sci. 82:295-304.

Holtenius, K., S. Agenäs, C. Delavaud, and Y. Chilliard. 2003. Effects of feeding intensity during the dry period. 2. Metabolic and hormonal responses. J. Dairy Sci. 86:883-891.

Ingvartsen, K. L. 2006. Feeding- and management-related diseases in the transition cow: Physiological adaptations around calving and strategies to reduce feeding-related diseases. Anim. Feed Sci. Technol. 126:175-213.

Lacetera, N., D. Scalia, U. Bernabucci, B. Ronchi, D. Pirazzi, and A. Nardone. 2005. Lymphocyte functions in overconditioned cows around parturition. J. Dairy Sci. 88:2010-2016.

Laeger, T., S. Görs, C. C. Metges, and B. Kuhla. 2012. Effect of feed restriction on metabolites in cerebrospinal fluid and plasma of dairy cows. J. Dairy Sci. 95:1198-1208.

Macdonald, K. A., and J. R. Roche. 2004. Condition scoring made easy. Pages 1-44 in Condition Scoring Dairy Herds. 1st ed. Dexcel Ltd., Hamilton, New Zealand.

Martin, P., and P. Bateson. 1993. Measuring Behaviour. An Introductory Guide. 2nd ed. Cambridge University Press, Cambridge, UK.

Matthews, L. R., C. Cameron, A. J. Sheahan, E. S. Kolver, and J. R. Roche. 2012. Associations among dairy cow body condition and welfare-associated behavioral traits. J. Dairy Sci. 95:2595-2601.

Moyes, K. M., J. K. Drackley, D. E. Morin, S. L. Rodriguez-Zas, R. E. Everts, H. A. Lewin, and J. J. Loor. 2010. Mammary gene expression profiles during an intramammary challenge reveal potential 
mechanisms linking negative energy balance with impaired immune response. Physiol. Genomics 41:161-170.

Phillips, C. J. C., and K. Hecheimi. 1989. The effect of forage supplementation, herbage height and season on the ingestive behaviour of dairy cows. Appl. Anim. Behav. Sci. 24:203-216.

Roche, J. R. 2007. Milk production responses to pre- and postcalving dry matter intake in grazing dairy cows. Livest. Sci. 110:12-24.

Roche, J. R., and D. P. Berry. 2006. Periparturient climatic, animal, and management factors influencing the incidence of milk fever in grazing systems. J. Dairy Sci. 89:2775-2783.

Roche, J. R., P. G. Dillon, C. R. Stockdale, L. H. Baumgard, and M. J. VanBaale. 2004. Relationships among international body condition scoring systems. J. Dairy Sci. 87:3076-3079.

Roche, J. R., N. C. Friggens, J. K. Kay, M. W. Fisher, K. J. Stafford, and D. P. Berry. 2009. Invited review: Body condition score and its association with dairy cow productivity, health, and welfare. J. Dairy Sci. 92:5769-5801.

Roche, J. R., J. K. Kay, and E. S. Kolver. 2005. Influence of precalving feed allowance on periparturient metabolic and hormonal responses and milk production in grazing dairy cows. J. Dairy Sci. 88:677-689.

Roche, J. R., J. M. Lee, K. A. Macdonald, and D. P. Berry. 2007a. Relationships among body condition score, body weight, and milk production variables in pasture-based dairy cows. J. Dairy Sci. 90:3802-3815.

Roche, J. R., K. A. Macdonald, C. R. Burke, J. M. Lee, and D. P. Berry. 2007b. Associations among body condition score, body weight, and reproductive performance in seasonal-calving dairy cattle. J Dairy Sci. 90:376-391.

Rook, A. J. 2005. Optimising the use of grazed herbage in the dairy cow diet. Cattle Practice 13:77-80.

Rushen, J., A. Boissy, E. M. Terlouw, and A. M. de Passillé. 1999. Opioid peptides and behavioral and physiological responses of dairy cows to social isolation in unfamiliar surroundings. J. Anim. Sci. 77:2918-2924.

Thomas, T. J., D. M. Weary, and M. C. Appleby. 2001. Newborn and 5-week-old calves vocalize in response to milk deprivation. Appl. Anim. Behav. Sci. 74:165-173.

Tucker, C. B., S. J. Lacy-Hulbert, and J. R. Webster. 2009. Effect of milking frequency and feeding level before and after dry off on dairy cattle behavior and udder characteristics. J. Dairy Sci. 92:3194-3203.

Tucker, C. B., A. R. Rogers, G. A. Verkerk, P. E. Kendall, J. R. Webster, and L. R. Matthews. 2007. Effects of shelter and body condition on the behaviour and physiology of dairy cattle in winter. Appl. Anim. Behav. Sci. 105:1-13.

Valizaheh, R. D. M. Veira, and M. A. G. von Keyserlingk. 2008. Behavioural responses by dairy cows provided two hays of contrasting quality at dry-off. Appl. Anim. Behav. Sci. 109:190-200.

Ward, J. R., D. M. Henricks, T. C. Jenkins, and W. C. Bridges. 1992. Serum hormone and metabolite concentrations in fasted young bulls and steers. Domest. Anim. Endocrinol. 9:97-103. 